Revista de la red interuniversitaria de estudios sobre las literaturas rioplatenses contemporáneas en Francia

21 | 2020

Glosolalias transplatinas: fantasmas, utopías y ficciones lingüísticas

\title{
Escribir en francés una literatura extranjera
}

Écrire en français une littérature étrangère

Writing a Foreign Literature in French

\section{Antoine Volodine}

Translator. Florencia Justo

\section{(2) OpenEdition}

\section{Journals}

Electronic version

URL: http://journals.openedition.org/lirico/9901

DOI: $10.4000 /$ lirico.9901

ISSN: 2262-8339

\section{Publisher}

Réseau interuniversitaire d'étude des littératures contemporaines du Río de la Plata

\section{Electronic reference}

Antoine Volodine, «Escribir en francés una literatura extranjera», Cuadernos LIRICO [En línea], 21 | 2020, Publicado el 13 julio 2020, consultado el 29 enero 2021. URL: http://journals.openedition.org/lirico/ 9901 ; DOI: https://doi.org/10.4000/lirico.9901

This text was automatically generated on 29 January 2021.

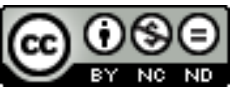

Cuadernos LIRICO está distribuido bajo una Licencia Creative Commons Atribución-NoComercialSinDerivar 4.0 Internacional. 


\title{
Escribir en francés una literatura extranjera
}

\author{
Écrire en français une littérature étrangère \\ Writing a Foreign Literature in French
}

Antoine Volodine

Translation : Florencia Justo

\section{EDITOR'S NOTE}

Antoine Volodine (alias Manuela Draeger, alias Elli Kronauer, alias Lutz Bassmann) es un novelista nacido en Francia en 1950. En la crítica literaria de ese país, tanto su nombre como el de sus heterónimos están asociados con una categoría estética -el post-exotismo- forjada por el mismo escritor. El crítico Lionel Ruffel, en su ensayo Antoine Volodine post-exotique (Nantes, Cécile Defaut, 2007), ha definido el post-exotismo como un "realismo socialista mágico", un estilo imposible en que lo político es procesado por una "biblioteca deformada" llena de géneros literarios inhallables en otro autores. Según ha declarado Volodine, sus personajes son "mujeres y hombres desviados, sin estatuto social, condenados a hablar desde lo más bajo de la escala social o mental" (entrevista con Philippe Savary, 2007). Además de novelista, Volodine es traductor (del ruso y del portugués); entre las obras que ha vertido al francés destaca $E l$ albergue del alpinista muerto (1970), novela de los hermanos Boris y Arcadi Strugatsky, quienes supieron inspirar a Tarkovski y a M. John Harrison. El texto que presentamos reproduce una conferencia pronunciada por el autor el 14 de diciembre de 2001 en la Biblioteca Nacional de Francia. Fue publicado originalmente en Chaoï, nº 6, París otoño-invierno de 2002. 


\section{Introducción}

1 Hace ya veinte años, empecé a escribir para un público. Pero ese no fue el comienzo de la escritura para mí. Ya antes había escrito varios libros. Porque desde la infancia, desde la adolescencia, digamos, yo escribía. Componía novelas y libros de cuentos que correspondían exactamente a mi gusto y a mis expectativas de lector. Como lo hacía por placer y no para obtener a través de mis textos un reconocimiento social, un estatuto intelectual, no los imponía a la gente de mi entorno. No los daba a leer, ni siquiera a las personas de mi círculo más íntimo. Así pues, durante mucho tiempo, durante casi quince años, escribí libros para un público minúsculo. Libros insólitos, fantásticos, oníricos y clandestinos, que se dirigían a un único lector.

2 Luego, se publicó una primera novela, Jorian Murgrave, y me puse a trabajar para satisfacer a un verdadero público. Empecé a imaginar a los lectores que podía tener: un público real, compuesto de hombres y mujeres que compartían la misma sensibilidad literaria y los mismos gustos que yo. Compartían conmigo la misma visión del mundo, los mismos miedos, las mismas certezas, deseaban compartir los mismos sueños $\mathrm{y}$, digámoslo sin más, la misma rebelión contra el mundo tal como es, contra la condición humana en sus aspectos políticos y metafísicos.

3 Y así, muy naturalmente, mis libros publicados prolongaron la tradición de los libros no publicados que los habían precedido. Alrededor de la novela y en la novela, suponían una fuerte empatía entre quienes hablaban y quienes escuchaban. En mis universos imaginarios, introduje lectores que no eran neutros. Mis libros suponían al principio una cultura común a los narradores y auditores, una memoria común, una sensibilidad literaria y humana común. Libro tras libro, esa memoria y esa cultura se fueron construyendo. Se fueron precisando, se fueron profundizando. Finalmente, todo eso tomó la forma concreta de un edificio novelesco, que hoy incluye unas quince obras.

4 En mi mente y en la mente de mis personajes, que a menudo ocupan un lugar fuera de la sociedad -fuera, incluso, de la especie humana-, aunque siguen siendo escritores y narradores, la ficción no necesita apoyarse en una realidad periodística, cotidiana, para existir. El conjunto es realista y a veces hiperrealista, los personajes mueren, sufren, se enamoran, combaten, pero la relación con el mundo geográfico e histórico contemporáneo siempre está muy deformada, un poco como en un sueño, en el que la memoria combina lo familiar y lo extraño. Es una relación en la que el lector se halla sumido en el centro de una realidad donde todo está por descubrirse, y donde hay que pasar por la memoria colectiva y el inconsciente colectivo para recobrar la familiaridad. Hablaré de esto con más detalle enseguida.

5 Hay un aspecto de esta exterioridad en el que me gustaría insistir. Esa masa novelesca fue escrita, fue construida sin tener en cuenta los gustos, las tendencias, las tradiciones del mundo editorial en el que ocupa un lugar. Hasta principios de los años 90, aunque ya había publicado varias obras, mi conocimiento de la literatura francesa contemporánea era absolutamente nulo. Escribía por instinto textos que sentía la urgencia de escribir para mí y para mi público imaginario, pero sin preocuparme ni un segundo por el mundo literario concreto en el que iban a terminar. En cuanto a los debates teóricos sobre la literatura que agitaban el mundillo de la crítica francesa, y que desde hace treinta años influyen considerablemente en las nuevas generaciones de autores franceses, no se me ocurrió introducirme en ellos produciendo textos influidos por tal o cual escuela. Sentía que no me concernían. Para mí, eso era el planeta Marte. 
Cuando empecé a formar parte de los autores de la editorial Minuit, en 1990, nunca había escuchado hablar del minimalismo. Siempre me he mantenido al margen de aquellos conflictos y pasiones, muy, muy lejos, con información siempre muy rudimentaria sobre esos asuntos.

Para simplificar, se puede decir que, desde el principio, mis novelas han sido ajenas a la realidad literaria francesa. Forman un objeto literario publicado en lengua francesa, pero pensado en una lengua exterior al francés, indistinta en cuanto a su nacionalidad. Una lengua no vinculada a un área geográfica determinada, y claramente "extranjera", puesto que no vehicula la cultura y las tradiciones del mundo francés o francófono.

\section{La lengua}

7 Quisiera detenerme precisamente en este problema de la lengua.

8 La idea falsa más extendida es que escribir en francés significa obligatoriamente ocupar un lugar en la cultura francesa y francófona. Se cree, sin reflexionar, que la lengua de un escritor conlleva por definición la herencia cultural, e incluso la huella de todos los escritores que han contribuido al prestigio de esa misma lengua durante siglos. Se cree, sin reflexionar, que la lengua de un escritor toma el relevo de todos los oradores eruditos y de todos los usuarios populares de esa lengua. Eso lleva a menudo a los escritores a sentirse investidos de un rol de representación diplomática, e incluso a reivindicar una "patria lingüística". Con arrogancia, con raptos líricos que me dan escalofríos, porque casi no veo la diferencia entre esas afirmaciones y un chauvinismo que detesto, escucho a los poetas y a los novelistas francófonos decir cosas peligrosas de este tenor: "Mi patria, la lengua francesa" o "Mi patria adoptiva, la lengua francesa."

9 Cada uno, pues, tiende a pensar que es un buen ciudadano de su propia lengua (lengua materna o adoptiva), y que tiene el deber moral e intelectual de atar esta lengua a un territorio nacional, a instituciones, a una historia, a poblaciones precisas y a una bandera. Un buen ciudadano e incluso un ciudadano agresivo, dispuesto a luchar para defender su identidad nacional.

Pero, si bien es cierto que la lengua vehicula toda la historia, buena y mala, del país o de los países donde es hablada, y, en lo que nos atañe, toda su historia poética e intelectual, también vehicula muchos otros elementos tomados de otros lugares.

11 Porque la lengua es también (y muy, muy ampliamente en nuestra época, en los últimos cincuenta años) un inmenso territorio internacional. Es un territorio indiferenciado que ha recibido las traducciones de muchísimas otras lenguas del mundo, y que no solamente las ha recibido, sino que las ha adoptado, llevado consigo, integrado. La lengua es una herramienta neutra que acoge todos los componentes de la humanidad, y que ya no puede ser anexada por un único componente nacional. En tanto y en cuanto las traducciones existen, cada lengua del mundo lleva en sí la herencia de TODAS las culturas del mundo.

Apoyándome en este razonamiento, me gusta decir que el chino es la lengua de los poetas de la dinastía Tang, la lengua de las largas novelas del siglo XVII (Si da qi shu), la lengua del teatro-ópera, la lengua de los excelentes novelistas chinos contemporáneos reunidos en esta sala, pero que es también, ya que las traducciones existen y han sido difundidas, la lengua de Beckett, de Dostoievski, de Balzac, de Dos Passos, la lengua de El libro tibetano de los muertos. 
$13 \mathrm{Y}$, del mismo modo, se puede decir que el francés literario es también la lengua de $E l$ libro tibetano de los muertos, la lengua de Pushkin, la lengua de Li Bai: dicho de otro modo, una lengua que contiene culturas, filosofías, preocupaciones poéticas y literarias que no tienen nada que ver con las costumbres de la sociedad francesa ni del universo francófono.

14 Pues bien, me he esforzado por escribir mis libros en esta lengua de traducción, en el plano del vocabulario y de la sintaxis, con toda la versatilidad, la riqueza y el genio de la lengua francesa, pero para ponerla al servicio de una cultura ajena a las costumbres de la sociedad francesa y al universo francófono.

lengua de mis libros conlleva, ante todo, la cultura de mis personajes, de los escritores-chamanes que pongo en escena y de los lectores que imagino. Conlleva su cultura subversiva, cosmopolita y marginal, una cultura de soñadores y de luchadores políticos que han perdido todas sus batallas y que todavía tienen el coraje de hablar, aun cuando perdido la batalla contra el silencio. Es por todo ello que hoy, aquí, yo no soy el embajador de la lengua francesa. Soy solamente embajador de mis personajes. ¿Cómo es el lenguaje en el que se expresan? Una lengua variada y a veces pobre, a veces mutilada o, al contrario, lujuriosa y barroca. Su lengua no es una lengua nacional, sino la lengua transnacional de los cuentacuentos, de los excluidos, de los prisioneros, de los locos y los muertos. Aquí soy el portavoz de sus voces. En mis libros, traduzco al francés las ficciones que ellos producen para protestar contra lo real, para sabotear lo real o para transformar lo real.

Eso es todo con respecto a la lengua.

\section{El universo extranjero, la memoria familiar}

Volveré ahora a la cuestión del carácter verdaderamente extranjero de esta literatura. Cuando una novelista china como Ying Chen, por ejemplo, escribe en francés, traduce y transmite en francés una cultura china, que no es extranjera sino desde un punto de vista francés, pero que no lo es, por supuesto, para los lectores familiarizados con China. Es una cultura de la que se puede decir que es relativamente extranjera. Pero para mí, escribir en francés una literatura extranjera no es solamente alejarme de la cultura francófona, sino también evitar que los puntos de referencia de la ficción remitan a un país determinado, geográficamente situado en un mapa. Intento explorar y representar una cultura no relativamente, sino ABSOLUTAMENTE extranjera.

\section{Los nombres}

18 Presto así una atención particular a la elección de los nombres de mis personajes. Es mediante la nominación de los narradores como se puede dibujar un territorio cultural preciso. Es algo que trato de evitar.

Mis personajes tienen nombres culturalmente híbridos. Por ejemplo: Dondog Balbaïan, Jessie Loo, Volup Golpiez, Irma Kobayashi, Anton Breughel, John Schlumm, Manuela Draeger, Maria Schrag, etc.

En ningún caso el narrador remite con su nombre a una identidad nacional precisa, con la salvedad de mi novela Lisbonne, dernière marge, en la que la heroína Ingrid Vogel es una terrorista de la Fracción del Ejército Rojo, en 1977. (Y, a propósito de esto, quisiera 
recordar que en mis libros hablo mucho de revolucionarios y combatientes armados, pero que son igualitaristas, generosos y anarco-comunistas; no tienen nada que ver con el islamismo, las guerras de religión o el asesinato en masa de civiles. Es solo un paréntesis).

De manera deliberada, entonces, impido que surja una imagen nacional de mis narradores. Estos se transforman en lo que yo quiero que sean: voces y nada más. Voces desfasadas, fuera de todo territorio y de toda etnia, voces internacionalistas de hombres y mujeres en combate contra las realidades desagradables del mundo. En reiteradas ocasiones me han dicho que los nombres de mis personajes hacían pensar en una lista de prisioneros de guerra, como en la Resistencia, cuando los nazis pegaban en las paredes listas de rehenes extranjeros. Acepto de buena gana esa imagen, sobre todo porque asocia la identidad extranjera a un combate mortal contra la opresión.

\section{Los lugares}

22 Además de los nombres de los narradores, que deberían vehicular automáticamente referencias culturales, y que aquí no lo hacen, los nombres de lugares tienen una gran importancia. El lector tiende a buscar en la escenografía puntos de referencia significativos. También en este aspecto he procurado siempre impedir toda identificación nacional. He procedido de acuerdo con estos tres métodos:

1. Los lugares están fuertemente definidos, pero no transmiten ningún valor nacional distintivo; por ejemplo: una cárcel en un país cálido, un dormitorio en un campo de exterminio, un hospital psiquiátrico, una ciudad tropical en ruinas, un pueblo al borde de un río, un paisaje de estepa, a veces un puerto chino anónimo, pero sin el exotismo que permitiría una identificación.

2. O bien sí menciono lugares, pero la denominación remite a una civilización imaginaria, desgarrada por la guerra civil desde hace siglos: por ejemplo, una aldea en la Amazonia, Puesto Libertad, o un inmenso territorio de Asia Central, la Balkhyria.

3. También sucede que los lugares son geográficamente identificables. En esas ciudades que se pueden encontrar en el mapa, y que elegí porque las conozco y me gustan, se desarrolla una parte de la ensoñación de los narradores: Lisboa, Macao, Hong Kong. Sin embargo, esos lugares se convierten en un escenario al que los personajes no están integrados, aunque a menudo intenten estarlo. El narrador no se encuentra allí como turista, pero sigue siendo extranjero. Se encuentra allí en tránsito o en exilio, en todo caso siempre en una situación inestable y nunca con el estatuto de un habitante normal del lugar.

\section{El tiempo}

La datación también podría remitir a una cultura nacional determinada. Sin embargo, en mis libros, en general, la acción transcurre en una época indefinida, como si rigiera un calendario histórico diferente del que conocemos. Históricamente, es un tiempo marcado por acontecimientos significativos y fuertes: por ejemplo, "dos mil años después de la revolución mundial", "en el período de entreguerras", "en la época de los campos", o "en los tiempos de la dominación de los brujos", o incluso "justo antes del fin de la especie humana". 
Todo esto fabrica contextos que anclan la ficción en una realidad, pero que la alejan de una realidad identificable histórica y geográficamente. Lo repito una vez más: lo que describo, lo que exploro, libro tras libro, es un universo realista, pero extravagante, absolutamente extranjero, cuyos personajes principales están poco familiarizados con el mundo de la economía liberal que nos rodea, puesto que son revolucionarios, golems, chamanes, enfermos mentales o subhombres.

Semejante edificio novelesco no tendría ninguna solidez si estuviese alimentado únicamente por lo fantástico y la fantasía. Sería similar a otras construcciones que atribuimos a la tradición literaria de lo maravilloso o del nonsense, o, más contemporáneamente, a la de ciertas vertientes de la ciencia ficción.

Mi objetivo está muy alejado de esas tradiciones. Deseo describir mundos interiores, zonas donde se reúnen el pensamiento consciente, el fantasma y el inconsciente en su forma doble: el inconsciente individual y el inconsciente colectivo. Quiero desplazar y desencarnar todo eso para que desaparezca toda posibilidad de vínculo nacional entre el narrador y la ficción. Quiero enlazar todo eso a una memoria que sea común a todos los individuos, sea cual sea su origen, $\mathrm{y}$, en términos generales, a todo ser humano que conozca la historia de la humanidad durante el siglo XX.

\section{La memoria colectiva}

30 He hablado del inconsciente colectivo. Lo que ante todo está en los orígenes de mi trabajo es la memoria colectiva. Hay, en efecto, una voluntad constante de apropiarse y de utilizar, en cada libro, en cada página, en cada momento, recuerdos comunes a los individuos que han atravesado el siglo XX. Más allá de los individuos, desde luego, y cualquiera que sea su experiencia real de los acontecimientos, está la experiencia histórica, a lo largo de varias generaciones.

Lenin profetizaba "un siglo de guerras y de revoluciones". Es ahí donde abreva la memoria de mis personajes. Lenin no se equivocó con su predicción, pero fue demasiado optimista. Su descripción premonitoria del siglo XX era incompleta. A las guerras y a las revoluciones se superpusieron las masacres étnicas, la Shoah y los campos, campos de concentración, campos de trabajo, campos de reeducación, campos de refugiados, y un largo etcétera, porque las variantes fueron numerosas.

2 El desafortunado siglo XX es la patria de mis personajes, es la fuente chamánica de mis ficciones, es el mundo negro que sirve de referencia cultural a esa construcción novelesca. La lengua de mis personajes no es una lengua nacional, es la lengua general de quienes padecen el infortunio y que, para contrarrestarlo, encuentran soluciones revolucionarias que podrían funcionar pero que no funcionan, soluciones insurreccionales que durante un momento efímero concretan una esperanza, y luego degeneran, se degradan, se convierten en un infortunio de otro tipo.

La lengua de mis narradores y de mis narradoras no es una lengua nacional; es en ciertos casos apenas una lengua humana, es la lengua de quienes, pese a sus esfuerzos, a lo largo de todo el siglo XX, solo han experimentado derrotas. Al referirse permanentemente a las tragedias archivadas en la memoria colectiva, mis personajes agotados toman la palabra y escriben libros. Hablan una lengua ajena al mundo real, recurren a formas literarias ajenas a la literatura del mundo contemporáneo, se 
expresan inventando formas novelescas inusitadas: romånces, Shaggås, entrevoûtes, narrats ${ }^{1}$.

34 Permítaseme aquí considerarme uno de ellos, escritores extranjeros y apátridas, para saludar fraternalmente a los escritores franceses y chinos presentes en este coloquio.

Gracias.

\section{NOTES}

1. [Géneros literarios inventados por A. Volodine.] 